\title{
'I presume she wanted it to happen': rape, reasonable belief in consent, and law reform in Northern Ireland
}

\author{
Eithne Dowds \\ Queen's University Belfast* \\ Correspondence email: e.dowds@qub.ac.uk
}

\begin{abstract}
In Northern Ireland (NI), determinations of whether the crime of rape has occurred require consideration of the accused's reasonable belief in the complainant's consent (the 'reasonable belief threshold'). Drawing on the rich body of feminist scholarship critiquing this threshold, this article makes two core contributions. First, through a thematic analysis of trial transcripts and news reports from the high-profile 2018 'Rugby Rape Trial' in NI, the article illustrates how trial narratives around consent and reasonable belief in consent 'responsibilise' the complainant while minimising the (in)actions of the accused. Second, the article evaluates the proposal in the 2019 Gillen Review that this threshold should be reworded to take account of the accused's failure to take steps to ascertain the complainant's consent. It is argued that, while this proposal has the potential to subtly redistribute narratives of responsibility, such potential can only be realised through a change in prosecutorial practice to ensure attention to the 'steps to ascertain consent' provision.
\end{abstract}

Keywords: rape; reasonable belief; consent; law reform; Rugby Rape Trial; Gillen Review.

\section{INTRODUCTION}

$\mathrm{O}$ $\mathrm{n}$ the 28 March 2018, the four defendants in a high-profile rape trial in Northern Ireland (NI), the 'Rugby Rape Trial', were acquitted on all charges. ${ }^{1}$ The trial concerned the alleged rape and sexual assault of a 19-year-old woman by Ulster and Ireland rugby players Paddy Jackson and Stuart Olding, as well as allegations of exposure and perverting the course of justice against Blane McIlroy and Rory Harrison, respectively. The trial featured heavily in the media due to the celebrity status of the defendants and, following the acquittal, public protests took place

* I am indebted to Professor Anne-Marie McAlinden, Dr Rachel Killean and Dr Olivia Smith for their invaluable feedback on earlier drafts of this article and to the anonymous reviewers for their helpful comments.

$1 \quad R v$ Patrick Jackson, Stuart Olding, Blane McIlroy and Rory Harrison (Crown Court, 28 March 2018). 
across NI and Ireland in support of the complainant. ${ }^{2}$ Legal inquiries into consent during this trial sparked outrage with some claiming the defence questioning of the complainant amounted to 'victim-blaming'3 and speculating whether a different approach to legally defining consent was needed. ${ }^{4}$ Significantly, consent was one of a range of issues evaluated as part of a subsequent review into the investigation and prosecution of sexual violence within NI. The final report from the review, led by Lord Justice Gillen (the 'Gillen Review') was published in May 2019 containing over 200 recommendations, including proposed changes to the substantive definition of consent. 5

The discussions in NI can be situated within the extensive body of critical rape scholarship on the treatment of complainants during the adversarial trial process. This includes the use of rape myths during cross-examination, 6 that is 'prescriptive or descriptive beliefs about rape that serve to deny, downplay or justify sexual violence', ${ }^{7}$ and reliance on such myths by (mock) juries. ${ }^{8}$ Rape myths can be particularly influential when it comes to determining the presence or absence of consent, as they shape expectations around how consent is communicated and understood during a sexual encounter. ${ }^{9}$ Scholars have also illuminated the role of the substantive law, despite decades of reform, in facilitating the use of and reliance upon rape myths. For

2 Brendan Hughes, 'Rugby Rape Trial: “I Believe Her" rallies planned across Ireland' Irish Times (Dublin 29 March 2018).

3 Eleanor Crossey-Malone, 'The Ulster Rugby Rape Trial: no to victim-blaming and rape culture' (Socialist Party 7 March 2018).

4 Emma Gallen, 'This is the real meaning of \#IBelieveHer for young Irish women' (Grazia 6 April 2018).

5 Sir John Gillen, The Gillen Review: Report into the Law and Procedures in Serious Sexual Offences in Northern Ireland (Department of Justice 2019) 377.

6 Olivia Smith and Tina Skinner, 'How rape myths are used and challenged in rape and sexual assault trials' (2017) 26(4) Social and Legal Studies 441-466; Olivia Smith, Rape Trials in England and Wales: Observing Justice and Rethinking Rape Myths (Palgrave Macmillan 2018); Elaine Craig, Putting Trials on Trial: Sexual Assault and the Failure of the Legal Profession (McGill-Queen's University Press 2018).

7 Gerd Bohner, Marc-André Reinhard, Stefanie Rutz, Sabine Sturm, Bernd Kerschbaum and Dagmar Effler, 'Rape myths as neutralising cognitions: evidence for a causal impact of anti-victim attitudes on men's self-reported likelihood of raping (1998) 28(2) European Journal of Social Psychology 257-268.

8 For an overview see, Fiona Leverick, 'What do we know about rape myths and juror decision making?’ (2021) 24(3) International Journal of Evidence and Proof 255-279. For research with real juries contesting belief in rape myths, see Cheryl Thomas, 'The 21st century jury: contempt, bias and the impact of jury service' (2020) 11 Criminal Law Review 987-1011. For a rebuttal, see J Chalmers, F Leverick and V Munro, 'The Dorrian Review and juries in rape cases: myths about myths?' (University of Glasgow School of Law Blog 2020).

9 Jacqueline M Gray, 'What constitutes a reasonable belief in consent to sex? A thematic analysis' (2015) 21(3) Journal of Sexual Aggression 337-353. 
instance, criticism has been directed at the 'reasonable belief in consent' threshold, that exists across many jurisdictions, including NI.10 This threshold requires that, to establish offences such as rape and sexual assault, the prosecution must prove not only that a complainant did not consent but that the defendant did not reasonably believe that the complainant consented. In determining whether a belief in consent is reasonable the jury can consider any steps taken by the defendant to ascertain consent, but the defendant is not obliged to take such steps. ${ }^{11}$ It has been suggested that the reasonable belief threshold encourages a disproportionate focus on the complainant's actions and reliance on problematic sexual scripts that assume consent in the absence of physical or verbal resistance. ${ }^{12}$ Although the tendency to focus on the complainant's actions is by no means new, 13 it has recently been situated within the neoliberal strategy of 'responsibilisation'. ${ }^{14}$ This is where individuals are expected to manage their own risk, with those who fail to prevent the alleged rape falling outside of dominant constructions of ideal victimhood: that is, those perceived as deserving of victim status because they are 'weak' and 'blameless'. 15

10 See eg Art 5(1)(c) Sexual Offences (NI) Order 2008; s 1(1)(c), Sexual Offences Act 2003; s 1(1)(b) Sexual Offences (Scotland) Act 2009; s 265.4.(4) Criminal Code of Canada 1985; s 128(2)(b) and (3)(b) Crimes Act 1961 (New Zealand); s 61HE Crimes Act 1900 (New South Wales).

11 Art 5(2) 2008 Order (n 10 above); Judicial College, The Crown Court Compendium Part I: Jury and Trial Management and Summing Up (December 2020) 20-17.

12 See eg Vanessa Munro, 'Constructing consent: legislating freedom and legitimating constraint in the expression of sexual autonomy' (2008) 41(4) Akron Law Review 923-956; Sharon Cowan, 'All change or business as usual? reforming the law of rape in Scotland' in Clare McGlynn and Vanessa Munro (eds), Rethinking Rape Law: International and Comparative Perspectives (Routledge 2010); Rachael Burgin and Asher Flynn, 'Women's behavior as implied consent: male "reasonableness" in Australian rape law' (2019) Criminology and Criminal Justice 1-19; Lucinda Vandervort, 'The prejudicial effects of "reasonable steps" in analysis of mens rea and sexual consent: two solutions' (2018) 55(4) Alberta Law Review 934-970.

13 See Rachael Burgin, 'Persistent narratives of force and resistance: affirmative consent as law reform' (2019) 59(2) British Journal of Criminology 296-314; Menachem Amir, 'Victim precipitated forcible rape' (1968) 58(4) Journal of Criminal Law and Criminology 493-502.

14 See David Garland, The Culture of Control: Crime and Social Order in Contemporary Society (University of Chicago Press 2001); Maddy Coy and Liz Kelly, 'The responsibilisation of women who experience domestic violence: a case study from England and Wales' in Carol Hagemann-White, Liz Kelly Thomas Meysen (eds), Interventions against Child Abuse and Violence against Women: Ethics and Culture in Practice and Policy (Verlag Barbara 2019).

15 See Lise Gotell, 'Rethinking affirmative consent in Canadian sexual assault law: neoliberal sexual subjects and risky women' (2008) 41(4) Akron Law Review 865-899; Nils Christie, 'The ideal victim' in Ezzat A Fattah (ed), From Crime Policy to Victim Policy: Reorienting the Justice System (Springer 1986). 
In response to these critiques, governments across the globe have begun to respond by way of law reform, with a visible trend towards the adoption of consent standards that encompass a communicative dimension. For example, while in NI and England and Wales attention must be paid to the complainant's state of mind when determining consent or the absence thereof for the purpose of the actus reus of an offence, ${ }^{16}$ other European jurisdictions have introduced affirmative models where attention is paid to whether consent is expressed by words or action. ${ }^{17}$ In jurisdictions across Australia, consideration has been given to whether, in determining the mens rea, the law should follow the approach in Canada by preventing a defendant from claiming that their belief in consent was reasonable if they did not explicitly seek consent. 18 The proliferation of law and policy in this area has given rise to a growing scholarship concerned with (i) reflecting on the failure of current consent standards; 19 (ii) attempting to 'make sense' of the new and emerging models of consent;20 and (iii) drawing out the theoretical and practical benefits, as well as drawbacks, of reform in this area. ${ }^{21}$

Building on this scholarship, this article makes two original contributions. First, while there is a significant empirical literature on rape and consent, 22 this article adds to the limited body of work drawing on trial transcripts. ${ }^{23}$ Through a thematic analysis of trial transcripts and news reports from the Rugby Rape Trial, the article illustrates how trial narratives around consent and reasonable belief in consent 'responsibilise' the complainant while minimising the (in)actions of the accused. Two core themes are identified: lack of resistance and/

16 See $R v$ Olubgoja [1982] QB 320, 5

17 See eg Act on the amendment of the Criminal Code, no 19/1940, with subsequent changes (sexual offenses) 2018 (Iceland); Criminal Code (Sweden) Brottsbalk (1962: 700) as amended in 2018, ch 6, s 1 .

18 See Rachael Burgin and Jonathan Crowe, 'The New South Wales Law Reform Commission Draft Proposals on consent in sexual offences: a missed opportunity?' (2020) 32(3) Current Issues in Criminal Justice 346-358; Rachael Burgin, 'NSW adopts affirmative consent in sexual assault laws. What does this mean?' (The Conversation 25 May 2021); s 273.2.(b) Criminal Code of Canada 1985.

19 See eg Burgin and Flynn (n 12 above); Burgin and Crowe (n 18 above).

20 See eg A Gruber, ‘Consent confusion' (2016) 38 Cardozo Law Review. 415-458; Jonathan Witmer-Rich, 'Unpacking affirmative consent: not as great as you hope, not as bad as you fear' (2016) 49 Texas Tech Law Review 57-87.

21 See eg E Dowds, 'Rethinking affirmative consent: a step in the right direction' in Rachel Killean, Eithne Dowds and Anne-Marie McAlinden (eds), Sexual Violence on Trial (Routledge 2021); Rona Torenz, 'The politics of affirmative consent: considerations from a gender and sexuality studies perspective' (2021) 22(5) German Law Journal 718-733.

22 See eg Smith and Skinner (n 6 above); Smith (n 6 above); Leverick (n 8 above).

23 See eg Burgin and Flynn (n 12 above); Burgin (n 13 above). 
or force during the encounter; and the dissection of the complainant's behaviour and consequently her non-ideal victimhood. ${ }^{24}$ It will be argued that, although some legal professionals attempt to counter these narratives, they remain dominant due to the reinforcement of these narratives by the defence and a lack of attention to the accused's responsibility to ascertain the complainant's consent. Second, the article makes a unique contribution to the debates on the utility of law reform by evaluating the proposal in the 2019 Gillen Review that the reasonable belief threshold should be reworded to take account of the accused's failure to take steps to ascertain whether the complainant consented. It is argued that, while this proposal has the potential to subtly redistribute narratives of responsibility, such potential can only be realised through a change in prosecutorial practice to ensure attention to the 'steps to ascertain consent' provision. ${ }^{25}$ Although the analysis in this article is focused on NI, the findings have broader significance and application in light of ongoing law reform across a range of comparative jurisdictions. ${ }^{26}$

At this juncture, it is important to note the methodological approach and boundaries of the research. Requests for written transcripts of NI court proceedings have to be approved by the Lord Chief Justice. Although the Rugby Rape Trial lasted 42 days, legal and procedural limitations associated with sexual offence cases meant I was only permitted to receive transcripts from seven days of the trial, covering some of the complainant's evidence in chief, some of her crossexamination and the judge's directions to the jury. ${ }^{27}$ As the court proceedings featured heavily in the media, news reports concerning the cross-examination of the accused, as well as counsel closing speeches, have also been drawn upon. The materials were analysed using a thematic approach identifying the various ways in which contested meanings of consent and belief in consent are constructed at trial. ${ }^{28}$ The approach utilised the dualistic technique of inductive

\section{Christie (n 15 above).}

25 Art 5(2) 2008 Order (n 10 above).

26 See eg New South Wales Law Reform Commission, Consent in Relation to Sexual Offences: Draft Proposals (2019); Queensland Law Reform Commission, Review of Consent Laws and the Excuse of Mistake of Fact (June 2020); Law Reform Commission of Ireland, Report on Knowledge or Belief Concerning Consent in Rape Law (November 2019).

27 This included respect for the complainant's right to anonymity resulting in access only being granted to files that had already been redacted.

28 See Virginia Braun and Victoria Clarke, 'Using thematic analysis in psychology' (2006) 3(2) Qualitative Research in Psychology 77-101. 
and deductive thematic analysis, ${ }^{29}$ allowing the review of the critical literature on rape to inform the initial analysis while leaving space for themes to develop direct from the data. It is acknowledged that defence counsel have a duty to test the evidence and to robustly challenge a complainant's account, and that the materials analysed in this article do not represent the entirety of the trial. Nonetheless, the article identifies lines of questioning that reinforce stereotypical assumptions about rape and contribute to what has been described as the secondary victimisation of complainants. ${ }^{30}$ While not suggesting that the findings are representative of all rape trials, an individual case study approach has been used by feminist scholars as 'a discursive site on which to expose and contest the gendered constructions of women's experiences'. 31

The article proceeds as follows. First, it sets out the socio-legal context of sexual violence in NI. Second, the Rugby Rape Trial and the Gillen Review are introduced. Third, it discusses the two core themes and findings from the empirical analysis of the Rugby Rape Trial, namely, the focus on force and resistance and the complainant's behaviour. Each theme is subdivided into two parts: defence narratives and counter-narratives by the prosecution/judicial directions. Fourth, it explores the extent to which the Gillen proposal on reasonable belief in consent could lead to a different trial narrative. The article concludes by reflecting on the far-reaching impact of trial narratives that rely on narrow stereotypical views of rape, responsibilise the complainant and obscure the responsibility of the accused; and highlights the need for careful intervention across multiple terrains, both legal and otherwise, if we are to trigger real and systemic change.

29 J Fereday and E Muir-Cochrane, 'Demonstrating rigor using thematic analysis: a hybrid approach of inductive and deductive coding and theme development' (2006) 5 International Journal of Qualitative Methods 80.

30 See eg Debra Patterson, 'The linkage between secondary victimization by law enforcement and rape case outcomes' (2010) 26(2) Journal of Interpersonal Violence 328-347.

31 Ashlee Gore, 'It's all or nothing: consent, reasonable belief, and the continuum of sexual violence in judicial logic' (2020) Social and Legal Studies 2. For an indepth exploration of a range of cases from NI, see L Kennedy, 'Bearing witness: report of the Northern Ireland Court Observer Panel 2018-2019' (Victim Support NI February 2021). 


\section{THE SOCIO-LEGAL CONTEXT OF SEXUAL VIOLENCE IN NORTHERN IRELAND}

Research has demonstrated that attrition - the process by which rape cases fail to proceed through the justice system - tends to be high across multiple jurisdictions. ${ }^{32}$ In NI, according to Public Prosecution Service (PPS) statistics, although 652 rape cases were passed for prosecution in 2019/2020, a prosecution or diversion decision was only made in respect of 73 of these cases, 33 and, while the Police Service of Northern Ireland (PSNI) has recorded between 900-1000 rapes each year from 2017-2020,34 only 10 rape convictions were secured in years $2017 / 2018$ and $2018 / 2019$, with a slight increase to 20 convictions in $2019 / 2020.35$ As these are recorded crime statistics, they do not present a complete picture. Indeed, it has long been established that rape is a notoriously underreported offence. ${ }^{36}$ For example, a 2019 survey of unwanted sexual experiences among NI students found that while 28 per cent of respondents had experienced some degree of unwanted sexual behaviour, only 5 per cent of those who told someone about their experiences had formally reported it, with 76 per cent believing it was not serious enough to report and 41 per cent believing it was not a crime. 37 Similar findings were reported in a 2017 study of non-consensual experiences among NI students, with feelings of shame and embarrassment among the reasons for non-reporting. ${ }^{38}$

Although complex feelings of shame or embarrassment are common among survivors of sexual violence, ${ }^{39}$ such feelings are heightened in the context of NI, a post-conflict jurisdiction with high levels of religiosity; a 'moral conservatism' around issues relating to sex,

32 See Jo Lovett and Liz Kelly, 'Different systems, similar outcomes? Tracking attrition in reported rape cases across Europe' (London Metropolitan University 2009).

33 Public Prosecution Service for Northern Ireland (PPSNI), Statistical Bulletin: Cases Involving Sexual Offences 2019/20.

34 PSNI, Outcomes of Crimes Recorded by the Police in Northern Ireland 2015/16 to $2019 / 20$.

35 See PPSNI, Statistical Bulletin: Cases Involving Sexual Offences 2018/19; PSNI (n 34 above).

36 See David Allen, 'The reporting and underreporting of rape' (2017) 73(3) Southern Economic Journal 623-641.

37 NUS USI Northern Ireland, ' 1 in 4 students in NI experience unwanted sexual behaviour' (27 March 2019).

38 Eimear Haughey et al, The Stand Together Report (The Student Consent Research Collaboration 2017).

39 See Office for National Statistics, 'Sexual offences in England and Wales overview: year ending March 2020'. 
sexuality and reproductive rights;40 and limited sex education.41 Further to this, a 2008 public survey of NI students found that victim-blaming attitudes were prevalent, with a significant number of respondents holding women responsible for sexual violence if they were drunk (44 per cent); flirted (46 per cent); failed to say no clearly (48 per cent); wore revealing clothes (30 per cent); had many sexual partners (33 per cent); or were alone in a dangerous/deserted area (47 per cent). 42 These views, while over a decade old, represent deep misunderstandings around sexual violence that are apparent in more recent studies. For instance, in 2018, Doyle and McWilliams reported that many participants in their study on domestic violence "viewed sex, consensual or not, as compulsory and as part of their "duty" as a wife/ girlfriend'. 43

The foregoing cultural issues contribute to the 'responsibilisation' of women and girls. Responsibilisation refers to the 'individualisation of risks that are generated structurally, with analysis and addressing of risk factors becoming a route to creating rational and responsible citizens'.44 Within the context of sexual violence, the existence of stereotypical views as to what constitutes a 'real'/'ideal' victim of rape, ie a chaste victim who sustains injury from being forcefully overpowered by an unknown assailant, 45 mean that women who fail to be 'responsible risk managers' 46 are blamed for what happened. The core of this article will explore how narratives of responsibilisation manifested during the Rugby Rape Trial and the extent to which recommended changes to the legislative definition of consent, as set out in the Gillen Review, can counter these narratives. Before doing so, it is necessary to provide more detail on this high-profile trial and the subsequent review.

40 See eg Jocelyn Evans and Jonathan Tonge, 'Partisan and religious drivers of moral conservatism: same-sex marriage and abortion in Northern Ireland' (2016) 24(4) Party Politics 335-346; Graham Ellison, 'Criminalizing the payment for sex in Northern Ireland: sketching the contours of a moral panic' (2017) 57(1) British Journal of Criminology 194-214.

41 See Ann Marie Gray, Louise Coyle, Rachel Powell and Siobhán Harding, Gender Equality Strategy Expert Advisory Panel Report (December 2020).

42 Amnesty International, 'New poll finds that almost half of Northern Ireland students believe that a woman is partially or totally responsible for being raped if she flirts' (Amnesty International UK 30 September 2008).

43 Jessica Doyle and Monica McWilliams, Intimate Partner Violence in Conflict and Post-Conflict Societies Insights and Lessons from Northern Ireland (PSRP Report 2018).

44 Coy and Kelly (n 14 above) 153.

45 See eg Susan Estrich, Real Rape: How the Legal System Victimizes Women Who Say No (Harvard University Press 1987). 


\section{The Rugby Rape Trial and the Gillen Review}

As noted in the introduction, in March 2018 Ulster and Ireland rugby players Paddy Jackson and Stuart Olding were acquitted of the alleged rape and sexual assault of a 19-year-old woman at a house party in 2016.47 In this case, the complainant had been on a night out with her friends in Belfast and went to an after-party at Jackson's house where the alleged rape and sexual assault occurred. The complainant testified that she had consensually kissed Jackson in his bedroom, but said 'no' to the remainder of the sexual activity, which included an act of oral sex on Olding when he entered the room. ${ }^{48}$ The defendants claimed the encounter was consensual, 49 and Jackson argued that only digital penetration had occurred between him and the complainant as opposed to penile penetration as alleged by the complainant. 50 During the trial, which lasted nine weeks, the complainant was cross-examined over a period of eight days by four defence counsel, her bloodied underwear was admitted as evidence and misogynistic WhatsApp messages shared between the defendants following the alleged incident were exposed in court. 51

In April 2018, the Northern Irish Criminal Justice Board commissioned a review of the law and procedure in prosecutions of serious sexual offences. 52 The review, led by Lord Justice Gillen, covered a range of issues and, of significance to this article, provided the opportunity to revisit the legislative definition of consent.53 According to the Sexual Offences (NI) Order 2008, consent is defined as agreement by choice, where the person has the freedom and capacity to make that choice. 54 This definition is supplemented by presumptions against consent, including where violence is used or the complainant is detained or is deceived as to the nature or purpose of the act. 55 In determining the guilt of a defendant, the Order provides that consideration must be given to whether they reasonably believed the complainant consented and, in assessing reasonableness, attention should be paid to all the circumstances including any steps the defendant took to ascertain whether the complainant consented. ${ }^{56}$ Following

For overview, see Killean et al (n 21 above).

Trial Transcript 5 February 2018 ICOS No 17/077669, 20 and 26.

Trial Transcript 23 March 2018 ICOS No 17/077669, 19.

Ibid 18.

See Killean et al (n 21 above).

Department of Justice, 'Review of Arrangements to Deliver Justice in Serious Sexual Offence Cases is Launched' (24 April 2018).

See Gillen (n 5 above).

Art 32008 Order (n 10 above).

Ibid arts 9 and 10 ).

See eg ibid art 5(1)(c) and 5(2). 
an exploration of definitions of rape in comparative jurisdictions, 57 as well as a period of consultation in NI, the Review concluded that more could be done to emphasise sexual choice as an underpinning principle of consent and to shift the focus away from the complainant's behaviour and towards the defendant's. 58 A key recommendation in this respect is that the definition as to what constitutes a reasonable belief in consent should be reframed, from requiring consideration of any steps taken by the defendant to ascertain consent when assessing reasonableness, to now requiring consideration of the defendant's failure to take steps to ascertain consent. 59

Drawing on a responsibilisation framework, the remainder of this article provides a detailed analysis of the operation of the current consent threshold within the context of the Rugby Rape Trial, followed by consideration of the extent to which the proposed rewording of the reasonable belief threshold offered by Gillen might impact trial narratives around consent.

\section{ANALYSIS OF THE RUGBY RAPE TRIAL}

The responsibilisation of the complainant is evident in two central narratives identified throughout the Rugby Rape Trial, primarily through defence questioning. The first focuses on a lack of physical force on the part of the defendants and a lack of physical resistance on the part of the complainant. Although not needed to satisfy the legal definition, 60 the defence narratives, particularly, rely on narrow constructions of rape. These included problematic expectations of how a rape victim should react that are embedded within social and cultural understandings of 'real rape'.61 The second, focused on the complainant's behaviour during the encounter and her non-ideal victimhood. This narrative played out in a way to construct the complainant's actions before and during the alleged encounter as either flirtatious or confusing and thus as suggestive of consent or open to misinterpretation.

57 These included jurisdictions focusing on: force and resistance (France, the Netherlands, Norway and some US states); 'no mean no' (Germany); and consent (England and Wales, New Zealand, Ireland, Scotland, South Africa, Sweden, Australia, Canada).

58 Gillen (n 5 above) 368-336.

59 Ibid 377. Additional recommended changes to the definition of consent include the introduction of a provision stating that passivity and a lack of resistance do not constitute consent, and the expansion of the list of presumptions against consent.

60 See $R v$ Malone [1998] 2 CAR 447.

61 Estrich (n 45 above). 


\section{Force and resistance}

Consent, it has been noted, is the central element distinguishing legal from illegal sexual activity. However, a significant body of research has demonstrated that the absence of consent, and even the presence of verbal refusal, often falls short of what is considered 'proof' of rape due to societal expectations that a 'real' rapist will use physical force and a 'real' victim will physically resist. 62 Such an expectation has its roots in historical legal requirements that defined rape as sexual intercourse with a woman by force and against her will, and the implicit, if not explicit, understanding that a victim must demonstrate 'utmost resistance'.63 These high evidentiary standards were the product of a deep mistrust of female sexuality and a patriarchal understanding of rape as a wrong against female chastity and male property. ${ }^{64}$ Although subsequent legal reforms centring consent sought to disrupt these narratives and better protect sexual autonomy, understood as the right to sexual self-determination, expectations of force and resistance persist. 65

\section{Defence narratives}

In the Rugby Rape Trial, narratives of force and resistance 66 were evident when the defence questioned the complainant about what happened following the consensual kiss between her and Jackson in his bedroom. The complainant's account was that Jackson tried to undo her trousers, but she said no and left the bedroom intending to leave the party. She realised that her clutch bag had been left upstairs and when she returned to get it, she alleged that Jackson pushed her onto the bed and raped her, Olding then entered the room and forced her to perform oral sex. The defence questioned the complainant on her positioning when she fell onto the bed:

Q. But, Ms.... there is no suggestion at all that he grabbed you or pulled you or lured you toward the middle of the bed so that you would fall back on to the middle of the bed. That's never suggested by you?

A. I just said it in my statement.

62 See eg ibid; Burgin (n 13 above); Graeme Walker 'The (in)significance of genital injury in rape and sexual assault' (2015) 34 Journal of Forensic and Legal Medicine 173-178.

63 For a detailed analysis, see Burgin (n 13 above).

64 Joan McGregor, 'The legal heritage of rape' in Jennifer Brown and Sandra Walklate, Handbook on Sexual Violence (Routledge 2011).

65 Burgin (n 13 above).

66 Burgin (ibid) similarly uses the term 'narratives of force and resistance' when analysing transcripts in from the County Court of Victoria, Australia. 
Q. Ms... what happened on that occasion was the same as what happened on the other occasion, I put it to you that you began to kiss him consensually again?67

The defence sought to emphasise the absence of traditional conceptions of force by noting that the complainant was not grabbed or pulled. The focus on the lack of force was also evident when the defendants were questioned by their counsel. For instance, Jackson was asked if he was party to a 'violent attack' on the complainant, if he had 'pull[ed] her through the doorway' and more generally if he had ever been violent to anyone else, to which he replied he had not. 68 This line of questioning works to differentiate what occurred in this case from that of the 'real rape' stereotype as described above.

The court heard excerpts from transcripts of police interviews with the defendants where similar narratives of (a lack of) force and resistance emerged. In response to a question about what made him think the complainant was consenting, Jackson said 'I didn't force myself on her. I presume she wanted it to happen. She didn't have to stay, she could have left.'69 In response to a similar question, Olding explained 'She didn't pull away. She kissed me back as well ... she was doing it and I wasn't forcing her.'70 These responses reflect socio-sexual scripts of women as sexual gatekeepers and consent as implied up and until a lack of consent is expressed. ${ }^{71}$ Research has shown that such scripts factor into deliberations of criminal liability, with one participant in a mock jury study, for example, noting: 'I know he didn't hear a yes, but he didn't hear a no, it's just too much to be able to say guilty.' 72 Thus, responsibility is often placed on women to verbalise their non-consent, and a lack of communication by men, as well as a reliance on inference, is normalised. This is reinforced by the inattention, beyond asking what made the defendants think there was consent, to how the defendants actually sought and received consent.

The emphasis on the complainant's lack of resistance continued when she was questioned by the defence about her response to the initial consensual encounter and the second encounter.

67 Transcript (n 48 above) 39 (emphasis added).

68 Jilly Beattie, 'Rugby star Paddy Jackson denies raping woman in his bedroom and claims she "was enjoying it"' (Irish Mirror 8 March 2018).

69 Conor Gallagher, 'Paddy Jackson: “'I didn’t force myself on her. I presume she wanted it to happen”' (Irish Times 23 February 2018).

70 Ibid.

71 See eg Kristen Jozkowski and Zoe Peterson, 'College students and sexual consent: unique insights'(2013) 50 Journal of Sex Research 517-523.

72 Emily Finch and Vanessa Munro, 'Breaking boundaries? Sexual consent in the jury room’ (2006) 26(3) Legal Studies 303-320, 317. 
Q. On the first occasion the evidence is that you gave him a firm 'no' and left the bedroom?

A. Yes.

Q. Why didn't you give him a firm 'no' this time and leave the bedroom?

A. Because he wasn't taking no for an answer. Everything about me was saying no. You can't underestimate how scared you are in these situations ...73

Suggesting that the complainant had returned upstairs to kiss the defendant, the defence argued that 'nothing was said by you nor shown by you nor rejected by you to show that you were not consenting'. ${ }^{74}$ While the complainant had recounted verbal refusals as well as pushing the defendant's hands away, she testified that she ultimately froze during the encounter. ${ }^{75}$ This claim is consistent with research into victim responses to sexual abuse, where, despite many believing victims will fight back, freezing is one of the most common responses. ${ }^{76}$ In the present trial, Dr Janet Hall, the defence's own forensic medical expert confirmed, in response to questioning from the prosecution, that, rather than resist, most victims of sexual assault 'allow it to happen' ${ }^{77}$ However, this evidence is likely to have become lost amongst Dr Hall's testimony in response to defence questioning where she disputed the initial medical exam carried out on the complainant, discussed below, and agreed that alcohol can 'make us behave in ways we wouldn't normally behave'.78

The court also heard evidence that a woman from the party walked into the room during the encounter and the defence questioned the complainant on why she did not seek help:

A. Because what was she going to do? It's one of those situations, she walked into that room, didn't actually know her. I thought she might be filming me. I turned around, registered it was a girl and turned my head the opposite direction in case she had been filming so I couldn't be identified.

73 Transcript (n 48 above) 40.

74 Ibid 44.

75 Ibid 40-44.

76 See Anna Möller, Han Peter Söndergaard and Lotti Helström, ‘Tonic immobility during sexual assault - a common reaction predicting post-traumatic stress disorder and severe depression' (2017) 96(8) Acta Obstetricia et Gynecologica Scandinavica 932-938.

77 Jilly Beattie, 'Medical expert tells Paddy Jackson and Stuart Olding Rugby Rape Trial that most victims "don't fight back"' (Irish Mirror 22 February 2018). Ibid. 
Q. What was she going to do you ask me. She might have helped you. She might have helped you and stopped them raping you, that's what she could have done, isn't it? Isn't it? She could have said stop, couldn't she? That's what she could have done. You asked me the question. Couldn't she have said stop?

\section{A. She could have, yes.}

Q. And you would have been able to point to the blood and the tears, if they were there, to confirm that you weren't consenting, couldn't you? ${ }^{79}$

The defence attempt to cast doubt on the complainant's testimony by constructing and reinforcing a 'rational ideal', 80 that is an ideal of a rational or logical response to rape shaped by myths, eg that the 'normal' reaction is to call for help, thus failing to account for the impact of trauma and emotion. The last question in the excerpt relates to injuries sustained by the complainant during the encounter. Despite narratives of a lack of force, the complainant testified that the defendants had been rough and that Jackson had tried to force his fist inside her; 81 there was also evidence of blood on Jackson's bedsheets. ${ }^{82}$ The doctor who examined the complainant following the incident reported that she had bruising to the elbow and kneecap 83 and a two to three centimetres internal tear, which he said had been caused by blunt force trauma but that he could not confirm whether this was consensual or not. ${ }^{84}$ Indeed, while the absence of injury is often used to suggest that rape did not occur, 85 the presence of injury is deemed inconclusive and open to dispute. ${ }^{86}$ In the present case, despite the defence question above linking the blood to the absence of consent, the defence argued that the source of the bleeding could not be confirmed and, rather than strengthening the prosecution's case, the fact that the complainant

79 Transcript (n 48 above) 48.

80 Smith and Skinner (n 6 above) 458.

81 Trial Transcript 31 January 2018 ICOS No 17/077669, 24.

82 Michael Donnelly and Ashleigh McDonald, 'Jackson and Olding rape trial: alleged victim's blood found on duvet from Jackson's bedroom' (Belfast Telegraph 21 February 2018).

83 Conor Gallagher, 'Belfast trial hears details of woman's injuries after alleged rape' (Irish Times 20 February 2018).

84 Ashleigh McDonald, 'Rugby Rape Trial: doctor can't say if intimate injuries from consensual or non-consensual sex' (Belfast Telegraph 20 February 2018).

85 See Walker (n 62 above)

86 Gethin Rees, “It is not for me to say whether consent was given or not”: forensic medical examiners' construction of "neutral reports" in rape cases' (2010) 19(3) Social and Legal Studies 371-386. 
had been bleeding formed the basis for intrusive questioning and the admission of the complainant's underwear in court. 87

While the source of the blood was disputed, the fact the complainant had been bleeding during the encounter was known to the defendants. In response to questioning by defence counsel, Jackson explained that he noticed blood on his fingers but 'thought it was something to do with her period. She didn't say anything and I didn't say to her. I thought it would have been a bit embarrassing for both of us.' 88 When asked whether he associated the blood with pain he responded in the negative and said that otherwise he "would have stopped. I would have asked if she was okay. If there was any pain I would have helped her.' 89 Beyond this questioning by the defence, there is nothing in the available transcripts or news reports exploring this issue further. The prosecution therefore missed a key opportunity to investigate the (in)actions of the defendants when the fact of the complainant bleeding was noticed: more attention to this aspect would have enabled engagement with the legal requirement to consider any 'steps' taken by the defendant to ascertain whether the complainant was consenting. ${ }^{90}$ The lack of attention to the (in)actions of the defendant, in comparison to those of the complainant, aptly demonstrates how "women become responsibilised at the same time as abusers become invisible and not held to account - de-responsibilised through this process of expecting women to manage their own safety'. 91

\section{Counter-narratives by the prosecution and judicial directions}

In terms of the construction of counter-narratives, some positive practices can be noted. For example, the prosecution challenged expert testimony presented for the defence in relation to the potential impact of alcohol on the complainant, as outlined earlier, noting that, while it is true that alcohol can reduce inhibitions and create arousal, "What is sauce for the goose is sauce for the gander.' 92 The prosecution also skilfully attempted to counter the narratives of force and resistance by moving beyond the physical. When questioning the defendants, the prosecution suggested that due to their alcohol intake there was a danger that they could 'disregard the wishes or views of another

87 Gráinne Ní Aodha. 'Underwear had to be shown in Belfast rape trial, says Jackson's lawyer' (The Journal.ie 24 November 2018). McDonald (n 84 above).

89 Ibid.

90 Art 5(2) 2008 Order (n 10 above).

91 Coy and Kelly (n 14 above) 154.

92 Beattie (n 77 above). 
person if they get in the way of what you want to achieve'.93 The prosecution highlighted the potential overpowering atmosphere due to the stature of the defendants in comparison to the complainant: 'Your work is physically engaging, using not only your skill but also your strength in an attempt to overpower your opponent. What match is a 19-year-old woman going to be for the pair of you if she is going to try to resist?'. ${ }^{94}$ Such questioning is infused with a sexual autonomy analysis, recognising the complex way power differentials can create situations of vulnerability and coercion, beyond traditional notions of force, and the way this can impact an individual's ability to offer resistance or 'just say no'.95

During the closing speech, the prosecution built on these arguments and emphasised the defendants' lack of interest in the complainant's consent, noting that ' $[\mathrm{H}] \mathrm{er}$ views are not sought' and that '[T]hey knew she did not consent, but they didn't care'. ${ }^{96}$ However, the defence kept issues of physical force and resistance alive in their closing speech by suggesting that the complainant had not been questioned thoroughly enough on these matters. Olding's barrister, for example, criticised police interviews with the complainant explaining that he would have asked: 'why she was unable to resist, why did she not say no?'; 'Why did she open her mouth - why didn't she keep her mouth closed?'; 'Why didn't she scream - the house was occupied. There were a lot of middle-class girls downstairs -they weren't going to tolerate a rape or anything like that'. 97 The reference to 'middle class' girls is extremely problematic and represents class stereotypes that led to public outcry during this case. 98 Olding's barrister also challenged the prosecution's case that the complainant had been frozen with fear, arguing that '[I] $\mathrm{f}$ someone performs oral sex for 5 minutes to the point of ejaculation does that not seem like consent?'99

93 'Rugby Rape Trial: Stuart Olding insists he and co-accused did not try to "cover up" what happened' (Irish News 8 March 2018).

94 Ibid.

95 See Burgin (n 13 above); Eithne Dowds, 'Towards a contextual definition of rape: consent, coercion and constructive force' (2020) 83(1) Modern Law Review 3563.

96 Jilly Beattie, 'Paddy Jackson and Stuart Olding Rugby Rape Trial hears coaccused's stories “don't add up"' (Irish Mirror 15 March 2018).

97 Nicola Anderson, 'Why didn't she scream? There were lots of girls downstairs who weren't going to tolerate a rape' (Independent.ie 22 March 2018).

98 See Seanín Graham, 'Campaign groups hit out at "middle class” women remarks in rape case' (Irish News 30 March 2018).

99 Jilly Beattie, 'Stuart Olding's barrister addresses jury at Rugby Rape Trial' (Belfast Live 21 March 2018). 
Jackson's lawyer similarly queried the prosecution's case, this time with regard to the woman who walked into the room. It was agreed that Jackson asked this woman to 'join in' and the defence argued that if she had agreed, '[I]s it really the Crown's case that half the bed would have been consenting and half not?'100 Jackson's lawyer also centred the closing speech around exaggerated understandings of 'real rape' that could be argued to be misleading101 in nature: 'What was it that she was genuinely in fear of? She tried to leave that room. Picture the scene. A dark alley miles away from people, gagged and locked up. Eight adults?'102 In this way the defence attempt to create a disjuncture between the complainant's account of what happened and stereotypical notions of 'real rape', often characterised by extreme violence.

Her Honour Judge Patricia Smyth QC attempted to balance the narratives during the summing up. Judge Smyth explained that the jury should 'leave behind all such assumptions' in respect of 'what constitutes rape. What kind of person might be a rapist. Or what a person who is being raped, or has been raped, would do or say.' 103 The judge went on to explain that there is no stereotype for a rape, a rapist or a victim of rape, or how people behave after they have been raped; that a victim of rape will experience trauma; that there are various reactions to rape such as freezing; and that every person reacts differently to the task of speaking about the rape.104 Judge Smyth outlined the legal meaning of consent as someone agreeing by choice and having the freedom and capacity to make that choice. A distinction was also drawn between consent and submission, with Judge Smyth explaining that consent given enthusiastically and consent given reluctantly are both valid consent, but that submission as a result of fear is not.105 In respect of the latter, it was noted that the prosecution does not have to prove that the fear was induced by force and there is no need to prove that the woman physically resisted or that she said that she did not consent. While such instructions aim to add clarity and speak to some

100 Lesley-Anne McKeown, “Prosecution's case is critically flawed”-Paddy Jackson's lawyer makes closing submission in rape trial' (Independent.ie 15 March 2018).

101 See eg the Bar Standards Board Handbook, Version 4.6 December 2020, part 2 'The Conduct Rules', r C6: 'Your duty not to mislead the court will include the following obligations: 1 you must not: a. make submissions, representations or any other statement; or b. ask questions which suggest facts to witnesses which you know, or are instructed, are untrue or misleading.' Smith and Skinner (n 6 above) 460 argue that clarifying what is meant by 'misleading' to include rape myths may tackle their use in court.

102 Beattie (n 68 above).

103 Transcript (n 49 above) 8-9.

104 Ibid.

105 Ibid 18-19. 
of the issues raised by the prosecution re fear felt by the complainant, the language of 'reluctant consent' has the potential to cause confusion. This is particularly true in a context where socio-sexual scripts often reframe women's refusal to male sexual advances as 'token' rather than real, complicating assessments of consent. 106 The judicial summary also discussed the fact that the complainant had been bleeding, but no mention was made of this being a point at which the defendants could, or should, have checked whether the complainant was consenting. In this regard, a judge's role at the point of summing up is to explain the law, summarise the relevant evidence and tell the jury how to approach the issues, ${ }^{107}$ and so the omission of this aspect can be linked to the fact that it was not presented more thoroughly during the trial.

\section{Complainant behaviour and (non-)ideal victimhood}

Stereotypical understandings of what constitutes 'real' rape and 'real' victimhood are an extension of what Christie has termed the 'ideal' victim: an individual deemed as deserving of victim status because they are weak, doing a 'respectable project', and cannot be blamed for being where they were. ${ }^{108}$ The ideal of respectability is particularly salient in the context of rape victimhood. While there has been a move away from the legal construction of rape as a property crime, key tenets of this conceptualisation, such as the focus on sexual purity continue to have profound implications on trial processes. ${ }^{109}$ Further to this, complainants are assessed against normative ideals of appropriate feminine behaviour whereby women are conditioned to appreciate the risk of violence and modify their behaviour accordingly. ${ }^{110}$ Where women fail to undertake this 'safety work',111 they are rendered complicit in their own victimisation due to their own (bad) choices especially if they engaged in 'risky' behaviour, that is drinking, flirting or dressing provocatively. ${ }^{112}$ Such behaviour may also be used to

106 See Eithne Dowds and Elizabeth Agnew, 'Rape law and policy: persistent challenges and future directions' in Miranda Horvath and Jennifer Brown, Rape: Challenging Contemporary Thinking 10 Years on (Routledge - forthcoming).

107 See Patricia Smyth, 'Sexual offence trials: the practical challenges for a judge tasked to deliver justice' in Killean et al (n 21 above).

108 Christie (n 15 above).

109 See eg Wendy Larcombe, "The "ideal" victim v successful rape complainants: not what you might expect' (2002) 10 Feminist Legal Studies 131-148; Clare McGlynn, 'Rape trials and sexual history evidence: reforming the law on thirdparty evidence' (2017) 81(5) Journal of Criminal Law 367-392.

110 Fiona Vera-Gray and Liz Kelly, 'Contested gendered space: public sexual harassment and women's safety' (2020) 44(4) International Journal of Comparative and Applied Criminal Justice 265-275.

111 Ibid.

112 Gotell (n 15 above) 866. 
imply consent on the part of the complainant or, where the trier of facts believes there was no consent, to suggest that the defendant nonetheless had an 'objectively' reasonable belief in consent. ${ }^{113}$

\section{Defence narratives}

In the Rugby Rape Trial, the defence sought to undermine the complainant's account by asking questions about her behaviour during the incident, and her character in general, that were imbued with assumptions about 'ideal victimhood', including perceptions around what is 'appropriate' versus 'risky' behaviour or 'rational' responses to rape. During cross-examination, the complainant was questioned about how she ended up at the house party and emphasis was placed on her behaviour at the nightclub prior to the party:

Q. You had no idea where [your friend] was, did you? You see is not the truth of what happened as far as outside Ollies is concerned, you were desperate to join the footballers party?

\section{A. That is incorrect.}

Q. That invitation was not forthcoming and you what you saw was Paddy Jackson and you waited some time and joined his party, his group, in his taxi? You weren't invited, were you? Not one of those girls invited you to Paddy Jackson's house. ${ }^{114}$

The emphasis on her not having been 'invited' to the party and as having left her friends can be situated within the responsibilisation framework whereby the woman who 'acts in ways that so exceeds the norms of sexual safekeeping ... becomes, in effect, a risky woman by virtue of the risk she poses to the masculine sexual subject' 115 - that risk stemming from perceived 'mixed signals' or 'sexual miscommunication',116 opening up the potential for future rape accusations that, as infamously stated by Sir Matthew Hale in 1736, are 'easily to be made and hard to be proved'. 117

The defence continued to focus on the complainant's behaviour by asking her about the consensual kiss in Jackson's bedroom. Acknowledging the kiss, the complainant explained that it was 'not indicative of consent for anything else'.118 The defence nonetheless questioned the complainant on where in the bedroom it took place:

113 See $R v$ Ewanchuk [1999] 1 SCR 330; Burgin and Flynn (n 12 above).

114 Transcript (n 48 above) 11-12.

115 Gotell (n 15 above) 893.

116 See eg Jozkowski and Peterson (n 71 above).

117 M Hale, History of the Pleas of the Crown (Sollom Emlyn 1736) 635.

118 Transcript (n 48 above) 20. 
Q. By the bed?

A. I'm not sure about that.

Q. Door open or closed?

A. I don't recall having to open a door so I presume the door was open. I'm not entirely sure on this.

Q. Ms..., Bedrooms are typically private places, aren't they? Would you agree?

A. Yes.

Q. Why did you, from downstairs at that party, where there was a toilet, a kitchen, a living room, why did you go upstairs to Paddy Jackson's bedroom, a private place? 119

The description of the bedroom as a 'private place' seeks to construct narratives of responsibility and implied consent: what other reason would the complainant have to be in the bedroom if not for sexual activity? The defence continued to construct a narrative of implied consent on the basis of the complainant's presence in the bedroom, as well as a narrative of flirting or attraction as consent: 120

Q. But why go to his bedroom?

A. I'm not entirely sure.

Q. You recall that text message we saw on Friday, that when you fancy someone you just can't keep your cool?

A. That is not applicable to this situation at all.

Q. So you were keeping your cool here, were you?

Q. It was witnessed by others that you were staring at Paddy Jackson?

A. I don't recall ever staring at Paddy Jackson.

Q. On more than one occasion, and possibly as many as three, Paddy Jackson left the living room area to go into the kitchen to fix drink for people and who would follow but you. Have you any recollection of that?

A. No, I do not.

119 Ibid.

120 See similar narratives in Burgin and Flynn (n 12 above). 
Q. And as and when you were in the kitchen, you would continue to stare at him, you were fixed on him? ${ }^{121}$

The defence also suggested the complainant was attracted to celebrities and that she had been 'teasing' Jackson before going to the bedroom on the first occasion. ${ }^{122}$ The focus on the complainant's behaviour prior to the alleged rape and sexual assault extended to her interactions with other men earlier in the nightclub. In defence closing remarks it was noted that the complainant had been tactile through the evening, touching the leg of one man and stroking the face of another.123 The admission of such evidence is extremely problematic as it rests on the flawed logic that flirting, even with other men, is indicative of consent to future sexual activity. As noted earlier, the complainant is responsibilised at the same time the defendant is de-responsibilised: the defence are implicitly suggesting that if the complainant had acted differently, eg by not flirting, the defendant would not have assumed that she consented. ${ }^{124}$ In this way, the defence seek to cast doubt over the complainant's 'innocence', and thus her 'victim status'.

Turning to the discussion of the complainant returning to the bedroom to get her bag after the first consensual incident, the defence sought to reframe the incident as a continuous consensual encounter:

Q. You were of a mind to leave because in part of his behaviour, because of what he done in the bedroom, why didn't you just put your hand on the chest of drawers, and take what you had come for and go down the stairs?

A. I can't remember if I checked the clutch or what, I'm really not sure.

Q. He was in the room, wasn't he?

A. I'm not sure. Like I said, the next thing I remember is Patrick Jackson standing at the bottom of the bed.

Q. But you see, Ms..., it's this, as has happened on the previous occasion, you had followed him up to his bedroom? ${ }^{125}$

The assumption underpinning this line of questioning is that the 'rational' response would have been to leave rather than go upstairs

121 Transcript (n 48 above) 21-25.

122 Ibid 29 and 42.

123 Lesley-Anne McKeown, “Prosecution's case is critically flawed” - Paddy Jackson's lawyer makes closing submission in rape trial' (Independent.ie 15 March 2018).

124 Burgin and Flynn (n 12 above).

125 Transcript (n 48 above) 37. 
and, because the complainant acted otherwise, the only credible conclusion is that the sexual activity was wanted. The reliance on these wider circumstantial factors legitimises stereotypical views about appropriate socio-sexual conduct, such as those found in the NI survey noted earlier, and normalise reliance on these issues when assessing whether a belief in consent was reasonable. Indeed, Finch and Munro report that in their mock jury study participants took account of similar factors when considering whether a belief in consent might be reasonable in all the circumstances, with one juror arguing that because the complainant, in the fictional scenario, had gone upstairs with the defendant it could reasonably be taken from this that she consented. 126

Ideals of socially accepted forms of rationality were also evident when the defence questioned the complainant about the fact that she recalled, during her evidence, asking Jackson to 'at least use a condom'.127 The defence asked: '[A]re you telling the jury that during the course of the rape you were asking Mr. Jackson to use a condom?'. ${ }^{28}$ This question is designed to present the complainant's actions as bizarre and create the foundation to frame the encounter as consensual. The characterisation of a complainant's reactions as irrational is a common defence strategy that rests on a narrow understanding of victim responses and a 'decontextualized view of risk avoidance'. ${ }^{129}$ A complainant might ask the defendant to wear a condom as a result of the inevitability of the attack and as an attempt to reduce the possibility of STI transmission or pregnancy. As Randall notes: '[S]ometimes ... women's resistance, though present, remains unseen and unrecognized, due to a limited and partial understanding of what resistance actually looks like and its many diverse and creative forms.' 130 It is thus clear from the foregoing analysis that the responsibilisation of the complainant is facilitated by a reliance on problematic views as to what constitutes 'real rape' or how an 'ideal victim' should behave.

\section{Counter-narratives by the prosecution and judicial comments}

In an attempt to address some of the claims made by the defence, the prosecution, in the closing speech emphasised the person- and situation-specific nature of consent, in that it must be given in respect

126 Finch and Munro (n 72 above) 318.

127 Trial Transcript 12 February 2018 ICOS No 17/077669, 43.

128 Ibid 65.

129 Gotell (n 15 above) 881; Smith (n 6 above) 187.

130 Melanie Randall, 'Sexual assault law, credibility, and ideal victims: consent, resistance, and victim blaming' (2010) 22 Canadian Journal of Women and Law 397-433, 420 . 
of each sexual encounter and each sexual partner. ${ }^{131}$ The prosecution explained that " $[\mathrm{T}]$ he law of this land is that a young woman is allowed to say "no"'.132 Reflecting on the first consensual encounter the prosecution continued, "[T] he law is not, "you let me kiss you so I can force myself upon you"... The law is not that "if I and my friend fancy he can join in and I can do as I please".'133 These comments attempt to present the defendants' mindset, a mindset the prosecution argued was one of 'male entitlement',134 as out of line with the current law on consent and reinforce the irrelevance of the circumstantial factors raised by the defence that rely on stereotypical assumptions about 'ideal' pre and post assault behaviour.

Similarly, Judge Smyth recounted the defences' argument that the complainant had been tactile and flirtatious with Jackson and other men throughout the night. She explained '... it would be wrong to leap to the conclusion that because she was drunk she must have been looking for or was willing to have sex or that someone else who saw and engaged with her could reasonably believe that she would consent to sex'.135 In doing so, Judge Smyth is challenging social and cultural narratives, discussed earlier, that use a complainant's pre-assault behaviour and 'non-ideal' victimhood to bolster claims of belief in consent. Judge Smyth also reminded the jury of the defences' claim that the only reason the complainant went up to Jackson's bedroom in the first place was to have sex and asked them to bear in mind that 'a woman is entitled to say "no" and to decide what sexual activity she wants, how far she is prepared to go and what she does not want to do'. ${ }^{136}$ While this statement again emphasises the situationspecific nature of consent, comments made earlier in the summing up potentially undermine these key principles. For instance, in discussing the dispute over why the first consensual encounter ended, with the complainant alleging Jackson had tried to take things too far and she left, whereas Jackson claims he left the room because the 'vibe' had changed as a result of the complainant teasing him about not knowing her name, Judge Smyth stated that 'your conclusions about this issue will be important when you are considering whether you are sure that [the complainant] did not subsequently consent to penetration. And if you are sure that she did not consent whether you are sure that Patrick

131 Conor Gallagher, "Belfast rape trial told alleged attack "a throwback to days of male entitlement”' (Irish Times 15 March 2018).

132 Beattie (n 96 above).

133 Ibid.

134 Ibid.

135 Trial Transcript 26 March 2018 ICOS No 17/077669, 23.

136 Ibid 28. 
Jackson did not reasonably believe that she consented.'137 Tying the two scenarios together in this way may create the impression that if the first consensual encounter ended as Jackson suggested then that consent can be transferred to the second encounter, or that it might at least justify his belief in consent.

Further to this, while Judge Smyth did explain that, in determining whether the defendants reasonably believed in consent the jury must consider all the circumstances including any steps taken by the defendants to ascertain consent, this aspect is not discussed in any detail by the prosecution or in the judicial direction. The emphasis throughout the trial is primarily on what the complainant did or did not do, and in line with comparative research, how she 'removed consent instead of how accused men gained it'.138 Now that the key themes from the analysis of the Rugby Rape Trial have been discussed, the next section considers the extent to which the recommendation made in the Gillen Review in respect to the reasonable belief threshold can impact trial narratives around consent.

\section{THE GILLEN RECOMMENDATION ON REASONABLE BELIEF IN CONSENT: WILL IT MAKE A DIFFERENCE?}

As discussed earlier, while the 2019 Gillen Review resulted in over 200 proposed legislative and policy changes, this article is concerned with the potential of the suggested reformulation of the reasonable belief in consent threshold:139 from requiring consideration of any steps taken by the defendant to ascertain whether the complainant consented when assessing reasonableness, to now requiring consideration of the defendant's failure to take steps to ascertain consent. ${ }^{140}$ However, it has already been noted that explicit attention to this threshold, and particularly any steps taken by the defendant to ascertain consent, was missing from the Rugby Rape Trial. While it is acknowledged that this finding relates only to one trial, it is consistent with court observation research from England and Wales, ${ }^{141}$ where the requirement to take steps was only implicitly referred to in one out of 18 sexual offence cases observed. The lack of attention to this provision can be linked to the fact that the defendant does not have to take steps to ascertain consent - it is a consideration only (and remains so under the proposed change) - and the perception that this provision is antithetical to the

137 Transcript (n 49 above) 22.

138 Smith and Skinner (n 6 above) 451.

139 Art 5(1)(c) and (2) 2008 Order (n 10 above).

140 Gillen (n 5 above) 377.

141 Smith (n 6 above) 138. 
'spontaneous' nature of sexual relations. ${ }^{142}$ Such a perception can be linked to the presumption that the steps requirement requires verbal communication and that asking for consent is 'awkward' or 'kills the mood'. ${ }^{143}$ While sexual communication can take many forms, including non-verbal cues, 144 the foregoing views raise questions around the real impact of Gillen's proposal.

Although Gillen's proposal is connected to an under-utilised legal provision, 145 it is suggested here that it may still have the potential to subtly redistribute narratives of responsibility and inform jury deliberations. For instance, under the current law the prosecution can ask the defendant what steps, if any, they took to ascertain consent and the defendant's response may feed into jury considerations of whether their belief in consent was reasonable. While such a question, if asked, may be framed in different ways, under the proposed law, the language of 'failure' provides the prosecution with the opportunity to question the defendant on particular instances during the encounter where further enquiries into consent could have been expected, and, where the defendant failed to do so, to ask them to account for this failure. ${ }^{146}$ As such, the course of evidence at trial may be affected in that the prosecution and defence would seek to elicit evidence, respectively, of the absence or existence of steps that the defendant took to ascertain whether the complainant consented.

By way of example, recall earlier, where the complainant had been bleeding during the encounter, the prosecution could have questioned the defendant as follows: "when you noticed the blood, did you ask the complainant if she was okay and if she wanted to continue with the sexual activity?' While the defendant may have responded, as he did when questioned by the defence, that he thought it would be embarrassing, the prosecution could press the point: 'So even though you knew the complainant was bleeding, you failed to check whether she was okay and whether she wanted to continue with the sexual activity because you decided it was better to avoid embarrassment?' This suggested questioning represents a situation where the defendant's, not the

142 Anna Carline and Clare Gunby, "How an ordinary jury makes sense of it is a mystery": Barristers' perspectives on rape, consent and the Sexual Offences Act 2003' (2011) 32 Liverpool Law Review 237-250, 247.

143 See eg Nicole Jeffrey and Paula Barata, 'The intersections of normative heterosexuality and sexual violence: university men's talk about sexual behavior in intimate relationships' (2019) 83 Sex Roles 353-369, 361.

144 See eg Jozkowski and Peterson (n 71 above).

145 Art 5(2) 2008 Order (n 10 above).

146 This approach is reminiscent of the Canadian approach, although the latter is stronger in the sense that where a defendant failed to take steps they are unable to rely on the defence of mistaken belief in consent. See $R v$ Malcolm 2000 MBCA 77 (CanLII), para 24. 
complainant's, actions can be called into question and, far from 'killing the mood', it could be argued that there was a heightened responsibility on the defendant to make explicit enquiries into the complainant's consent. 147 The prosecution could also use this situation to challenge the defendants' claim that they 'presumed consent' by asking questions along the lines of: 'you have stated that you presumed the complainant consented, did the fact that the complainant started to bleed not disrupt this presumption?' Such questioning challenges discourses of 'male sexual prowess' and claims that the defendant 'just knew' there was consent. 148

Similarly, the language of failure could be used by the prosecution when discussing the evidence relating to the woman who entered the room. It was noted that Jackson asked this woman if she wanted to 'join in', and the defence argued that this suggested the encounter was consensual. However, it could also be argued that the lack of communication with the complainant around any potential progression of sexual activity reinforces the prosecution's claim that the defendants did not care about the complainant's consent. The prosecution could have asked the defendant: 'before you asked $\mathrm{X}$ to join in, did you ask the complainant if she wanted another person to engage in the activity?' If the defendants said no or tried to frame it as joking the prosecution could have asked: 'so when seeking to progress the sexual activity and involve another person you failed to even speak to the complainant about her consent, wants or desires in that moment?' This line of questioning can disrupt stereotypical notions of female passivity and willingness to accept male sexual advances up and until the verbalisation of a 'no', and instead emphasise the importance of negotiation and communication, ${ }^{149}$ as well as the person- and situation-specific nature of consent as discussed earlier.

If such questioning was to be advanced, it could then be included as part of the judicial summary. For example, the current summary explains that the defendant 'said that while he was penetrating [the complainant] with his fingers he saw a little blood on his fingers. He said he didn't say anything and he thought it would have been embarrassing for both of them. He said there was no sign that the blood was associated with pain in any way and if it had been he would have stopped.' 150 If, in line with the proposed new law, the prosecution

147 Such questioning aligns with Anderson's 'negotiation model': see Michelle Anderson, 'Negotiating sex' (2005) 78 Southern California Law Review 101-138.

148 Anastasia Powell, Nicola Henry, Asher Flynn and Emma Henderson, 'Meanings of "sex" and "consent": the persistence of rape myths in Victorian rape law' (2013) 22(2) Griffith Law Review 456-480, 476.

149 See Anderson (n 147 above).

150 Transcript (n 135 above) 43. 
advanced the above questioning the judge could elaborate on this point by stating: 'the prosecution suggest that the fact that the defendant did not say or do anything at this point amounts to a failure to ascertain whether the complainant consented. This will be important to your consideration of whether the defendant reasonably believed that the complainant consented.'

It is not suggested that this line of questioning or additional judicial directions on the matter will change the verdict; indeed there are many factors that contribute to securing a rape conviction at trial and, further, this was not the stated aim of Gillen's proposal.151 Rather, as Gillen suggested, the reformulated reasonable belief threshold may shift attention to the perpetrator thus contributing to an important counternarrative. In this way, Gillen's proposal can help to rebalance the focus of the trial and disrupt dominant narratives that imply consent by highlighting the unreasonableness of a defendant's belief in consent. 152 However, the potential of this proposal can only be realised through a change in prosecutorial practice to ensure adequate attention to the 'steps to ascertain consent' provision, and not only when questioning the defendant. As such, if the law is to be amended, the PPS Policy for Prosecuting Rape Cases should be updated to reflect any changes and give direction to prosecutors on how best to incorporate questioning on this matter. ${ }^{153}$ In this respect, inspiration could be drawn from materials developed by Burrowes who designed a toolkit for prosecutors in England and Wales to, amongst other things, 'balance the focus of the case on D's behaviour, motives and reasons to assist in rebutting any assertion that $\mathrm{C}$ consented or $\mathrm{D}$ had a reasonable belief in consent, as well as assess the complainant's evidence'.154 In the context of the 'steps to ascertain consent provision' as it currently exists, Burrowes explains that this provision should be included in the prosecution's opening statement and the issue should be explored during the complainant's evidence-in-chief and in the closing address. ${ }^{155}$ Further to this, the additional measures set out in the Gillen Review, including those relating to various 'myth busters', such as a pre-trial video for jurors, written judicial directions on rape myths and stereotypes for jurors, and intervention at Ground Rule Hearings in the absence of the

151 See Gillen (n 5 above) 368-336.

152 Gillen's additional recommended changes to the definition of consent, such as including a provision stating that passivity and a lack of resistance do not constitute consent, while already provided for in common law, may also reinforce this position. See Gillen (n 5 above) 377.

153 PPSNI, Policy for Prosecuting Rape Cases, December 2010.

154 Nina Burrowes, 'Tool kit for addressing consent and associated myths for prosecuting advocates in rape trials'.

155 Ibid. 
jury if counsel propose inappropriate questioning, ${ }^{156}$ should also be used as a means to challenge problematic narratives including those relating to force, resistance and 'ideal' victimhood outlined in this article.

\section{CONCLUSION}

Drawing on critical feminist scholarship on rape, this article applied a responsibilisation lens to trial transcripts and news reports from the Rugby Rape Trial. In doing so, the article identified two central narratives that contribute to the 'responsibilisation' of the complainant: a lack of resistance and/or force; and the complainant's behaviour and (non)ideal victimhood. The article demonstrated how problematic extra-legal factors come to dominate the trial narrative at the expense of factors - such as attention to any steps taken by the defendant to ascertain consent - that, as a matter of law, should be considered when determining whether an offence has occurred. Indeed, in contrast to Hale's infamous pronouncement that rape is an accusation easily made and difficult to refute, effective scripted defence strategies have emerged over the years built on a suspicion of female sexuality and the normalisation of a male sexuality that, while active, is noncommunicative and can 'reasonably' expect sex from behaviour and inference. 157 Such scripts minimise and obscure the defendant's responsibility for the encounter leading to the 'impossibility' of rape. 158

Within the context of the adversarial criminal trial, such an 'impossibility' provides the foundation to discredit and undermine the complainant's lived experience which can lead to feelings of retraumatisation in what has been described as the 'second rape'.159 The dominant narratives constructed in the Rugby Rape Trial not only contribute to the potential secondary victimisation of the complainant, but also those who witness this treatment from the public gallery, news reports or through word of mouth. The consequence of these narratives are thus far reaching, telling those who have experienced sexual victimisation that this is not a safe space for you to bring your claim. Instead, as a wealth of literature has documented, $\mathbf{1 6 0}$ this is a space where you will be put on trial, you will be expected to demonstrate what you did to prevent the violation or explain why you

156 See Gillen (n 5 above) 214-216.

157 See eg Burgin and Flynn (n 12 above); Jeffrey and Barata (2019) (n 143).

158 Louise du Toit, A Philosophical Investigation of Rape: The Making and Unmaking of the Feminine Self (Routledge 2009) 97.

159 See Patterson (n 30 above).

160 See eg Smith (n 6 above); Craig (n 6 above); Burgin (n 13 above). 
did not respond in the socially expected way, with extremely limited corresponding expectations being placed on the defendant in relation to how they behaved in the situation.

This article considered the extent to which the proposal contained in the 2019 Gillen Review, that the reasonable belief in consent threshold should be reworded to take account of the defendant's failure to take steps to ascertain the complainant's consent, could disrupt these narratives. In this respect, it has been suggested that the proposal has the potential to subtly redistribute narratives of responsibility, as the language of 'failure' provides the prosecution with the opportunity to question the defendant on instances during the encounter where the responsibility to ascertain consent was heightened. In this way, there is potential for decisions as to whether an offence has been committed to no longer turn solely on what the complainant did or did not do, but that the actions or inactions of the defendant are central to these considerations. However, it has been recognised that any changes to the law in this area are unlikely to have an impact unless there is a change in prosecutorial practice to ensure the reasonable belief threshold, and particularly, the 'steps to ascertain consent provision' are explicitly dealt with as part of the trial narrative. Moreover, due to the deeply entrenched minimisation and misunderstanding of rape and sexual violence that form the 'cultural scaffolding'161 for the perpetration, justification and disqualification of such violence, interventions beyond the criminal justice system are required. The struggle against sexual violence requires attention to everyday micro-politics, critical reflection on our socio-sexual expectations and a willingness to challenge the narrow and stereotypical ideals of rape victimhood that create insurmountable barriers to redress and recognition for many who experience sexual victimisation. 